\title{
A STUDY ON FACTORS AFFECTING E-WALLET USAGE
}

\section{Gautam Parmar}

ASPEE Agribusiness Management Institute Assistant Professor, Navsari Agriculture University, Navsari

Email Id: gautamrparmar@gmail.com

\section{Dr. Raju M. Rathod}

Professor, G.H. Patel P.G. Institute of Business

Management, Vallabh Vidhyanagar

Email: rajumrathod@rediffmail.com

\begin{abstract}
The usage of E-Wallet is increasing rapidly in India. There are various growth drivers which plays a significant role in increasing the penetration of E-wallet like smartphone and internet penetration, $4 G$ technology. At present, mobile payments form a very small part of the overall digital payments industry in India. However, the contribution from phones and tablets are expected to increase to 30 per cent by 2020. The present study was conducted with the goal of studying factors affecting E-wallet usage. The Primary data have been collected through structured questionnaire to meet objectives by applying convenience sampling method. The exploratory factor analysis was employed to extract factors which yielded three factors namely perceived benefits and convenience, Experience Expectation and perceived risk Findings of the study would be helpful to design marketing strategy to increase the adoption of E-wallet among people.
\end{abstract}

Keywords: E-wallet, Digital Payments, Perceived Benefits of E-wallets, E-wallet Usage

\section{INTRODUCTION}

India is traditionally a cash-based economy, with the value of physical currency in circulation estimated to be over $11 \%$ of GDP, one of the highest among emerging economies (Hodiwalla F, Aneja, 2016). According to Assochem report, 2016 The size of the Indian economy was estimated at US\$2.07 Trillion (INR 132.7 Trillion) for the year 2015, compared to US\$2.04 Trillion (INR 124.5 Trillion) in 2014.According to IMAP 2016 report presently (2015), cash transactions account for $78 \%$ of all transactions in the country. But, the percentage of cash for transactions has seen a rapid decline in the past few years in India. In 2010 , the percentage of cash in all payments was $89 \%$ compared with $78 \%$ in 2015 . E payment is a subset of an e-commerce 
transaction to include electronic payment for buying and selling goods or services offered through the Internet. (Deepak Mathur, 2015) E-wallet is an online prepaid account where one can stock money, to be used when required. E-wallets are here to replace physical wallets in your pockets. (Jocil, 2017). The terms "mobile wallet" and "ewallet" are specific implementations of the digital wallet for the mobile device and for the desktop/browser environment, respectively. (Comviva, 2016). A digital wallet allows users to make electronic commercial transactions swiftly and securely. It functions much like a physical wallet. (Majid Taghiloo et.al, 2010). Digital wallets can be used in conjunction with mobile payment systems that allow customers to pay for purchases with their smart phones. (Deepak Mathur, 2015). According to Assochem report, 2016 Mobile wallet service is estimated to contribute $30 \%$ share in the mobile payment volume transactions in FY 2017. Mobile wallet transactions in India have grown approximately 20 times to reach INR 206 billion in FY 2016 from INR 10 billion in FY 2013. In FY 2016, the total m-wallet transaction was 0.6 billion; and it is expected to reach 260 billion by FY 2022, growing at a CAGR of $163 \%$.

\section{ADOPTION AND PERCEPTION OF E- WALLETS}

According to Assochem report, 2016 The Indian $\mathrm{m}$-wallet market is growing tremendously, backed by factors such as the rise in the usage of smart phones, increased penetration of mobile internet in the country and increasing disposable incomes. According to BCG Google report 2016, Supported by a favorable regulatory environment and coupled with a young demography eager to try and test new digital technologies, the Indian payment industry is bound to grow multi-fold in the coming decade. According to Stephen P Robbins, Perception is a process by which individuals organize and interpret their sensory impressions in order to give meaning to their environment and schiffman defines it as "the process by which an individual selects, organizes, and interprets stimuli into a meaningful and coherent picture of the world.

\section{METHODOLOGY}

The present research aims to study factors affecting E-wallet usage. To structured questionnaire was used to collect data from respondents which contains demographic details of respondents and research questions. The questionnaire was containing 18 
statements designed to investigate factors affecting towards e-wallet usage. Responses were obtained on a five-point Likert-type rating scale (strongly agree to strongly disagree). The researchers have developed the scale by reviewing literature investigate factors affecting towards e-wallet usage. To assess for internal consistency, Cronbach's alpha reliability coefficient was calculated for the 18 statements. A Cronbach's Alpha value obtained was 0.912 , which indicate the response scale had a good and acceptable internal consistency. The convenience sampling method was employed for the present study and sampling size was kept 99 respondents for present study. Total 99 respondents' data were obtained with the help of online survey. The descriptive statistics, chi square test and exploratory factor analysis are used to analyze the collected data.

To check out the association between demographic factors and adoption of e-wallet the Chi-square tests were used. For testing Chi-Square following null hypothesis were constructed.

$\mathrm{HAo}=$ Adoption of the e-wallet is independent of education level

HA1 = Adoption of the e-wallet is dependent on education level
$\mathrm{HBo}=$ Adoption of the e-wallet is independent of occupation

HB1 = Adoption of the e-wallet is dependent on occupation

$\mathrm{HCo}=$ Frequency of using E-wallet is independent of occupation

$\mathrm{HC} 1=$ Frequency of using E-wallet is dependent on occupation

\section{RESULT AND DISCUSSION}

The statistical tools employed for present study are frequencies, percentage, chi-square test and exploratory factor analysis. Exploratory factor analysis using principal component analysis approach was used to determine the most important variables from a large number of variables in the set of data that affect e-wallet usage.

The tables 1 shows demographic profile of respondents, for the present study 99 respondents was surveyed and out of those 78 respondents was male and 21 respondents were female. The average age of respondents was found 26 years ranging from 19 years to 60 years. The majority of respondents (65) studied up to post graduate followed by 26 respondent studied up to under graduate level. Most of the respondents were either students (64) or service class (30) whereas 2 respondents were doing business. The 39 


\section{ELK ASIA PACIFIC JOURNAL OF MARKETING \& RETAIL MANAGEMENT}

ISSN 2349-2317 (Online); DOI: 10.16962/EAPJMRM/issn. 2349-2317/2018; Volume 9 Issue 4 (2018)

respondents were spending less than $250 \mathrm{Rs}$ on mobile, 33 respondents were spending 250-500 Rs on mobile whereas 27 respondents were spending more than $500 \mathrm{Rs}$ on mobile. The average time spends on mobile by respondents found 3.42 hours per day. Out of the 99 respondents 81 respondents were using e-wallet whereas 18 respondents were not using e-wallet.

As shown in table no 2, the chi square test found significant at $5 \%$ significant level which shows the adoption of e-wallet is dependent on education level. Thus, it is indicating that adoption of e-wallet is influenced by education of person. The outcome of the test is in line with, "The more educated a person is, the higher will be his/her degree of acceptance of e - banking. (Odumeru, 2012)" and "Higher levels of education were associated with higher probabilities of being in the technophile group. (Jeanne M. Hogarth, 2008)". As shown in table no 3, the chi square test was not found significant at $5 \%$ significant level, which shows the adoption of e-wallet is independent of occupation. So adoption of ewallet is not influenced by occupation of person. As shown in table no 4 , the chi square test found significant at $5 \%$ significant level which shows there is association between frequency of using E-wallet and occupation

\section{RELIABILITY TEST ALPHA}

The respondents were asked to respond on 5 point Likert scale for 18 statements to investigate factors affecting e-wallet usage. To check reliability of the scale, As shown in table no 5 cronbach's Alpha was calculated and it was found 0.912 for 18 items. The reliability test Alpha was developed by Lee Cronbach in 1951 to provide a measure of the internal consistency of a test or scale; it is expressed as a number between 0 and 1 . (Tavakol et al. 2011). As a rule of thumb the value greater than 0.7 is good and acceptable. For the present study Cronbach's Alpha Based on Standardized Items obtained 0.912. So the data are reliable for further analysis.

The Bartlett's test of Sphericity and Kaiser Meyer-Olkin (KMO statistics) measure of sample adequacy were used to assess the suitability of data for carrying out the factor analysis. The value of Kaiser-Meyer-Olkin Measure of Sampling Adequacy test is accepted greater than 0.6. (Malhotra,2007) For the present study the Kaiser-Meyer-Olkin Measure of Sampling Adequacy value obtained is 0.888 and Bartlett's Test of Sphericity found significant. So, the factor analysis can be performed for the present data. (Table no.6) 


\section{EXPLORATORY FACTOR ANALYSIS}

Respondents were asked to answer 18 statements using 5-point Likert scales where 1 was strongly agree and 5 was strongly disagree to investigate factors affecting ewallet usage. The principal component extraction performed where the eigenvalue greater than 1 was considered. Varimax with Kaiser Normalization rotation method was employed in this analysis. The Rotated Component Matrix was presented sorted by size and the coefficients were suppressed having value below 0.4 . The factor analysis yielded 3 factors were which explains 63.272 $\%$ of total variance as shown in below table no 7.

The factor analysis yielded three factors namely perceived benefits and convenience, Experience Expectation and perceived risk (Table no 8).

The first factor can be named as perceived benefits and convenience due to high loading factors to the statements associated to the benefits and convenience which explained $35.648 \%$ of total variance having factor loading for the statements are ranging from 0.851 to 0.580 . Perceived usefulness is defined as "the degree to which a person believes that using a particular system would enhance his or her performance" Perceived usefulness according to Davis (1989) can be defined as the "degree to which the user believes that using a system would enhance their job performance.

The second factor can be named as Experience Expectation due to high loading factors the statements associated with the Experience Expectation. The factor explains $14.067 \%$ of total variance having factor loading for the statements are ranging from 0.765 to 0.694 .

The third factor can be named as Perceived risk due to high loading factors the statements associated to the Perceived risk. The factor explains $13.557 \%$ of total variance having factor loading for the statements are ranging from 0.876 to 0.778 .Perceived risk is defined as an assessment of uncertainties or lack of knowledge about the distribution of potential outcomes. (March, 1978)

The outcome of the study were in line with Technological Acceptance model (TAM) considers which perceived usefulness (PU) and perceived ease of use (PE) as two major factors influencing a user's attitude toward using technology (ATT) (Devis et.al,1989). Consumer acceptance was determined by four factors: perceived use, perceived ease of use, perceived risk, and compatibility (Chen,2008), perceived usefulness and ease 
of use are key determinants toward consumer acceptance and that consumers' attitudes toward accepting mobile wallets are strongly influenced by perceived security and trust.(Shin,2009). Perceived use, trust, expressiveness and perceived ease of use play a crucial role in facilitating adoption of mobile payment solution (Sanjeev Padashetty, 2013). Adoption of M-wallet has increased due to three main factors convenience, ease of use, compulsion after demonetization.(Teena Wadhera et.al, 2017).Perceived usefulness, perceived ease of use, consumer awareness and perceived risk are the important determinants of mobile banking adoption (Rahmath Safeena, 2012).The security issues, less technical knowledge and unavailability of internet in many places is still a major drawback for major uses of digital wallets in India. (Saini, 2017)

\section{INTERNAL CONSISTENCY}

The internal consistencies were checked using Cronbach's Alpha for three factors extracted by factor analysis. The Cronbach's Alpha for perceived benefits and convenience, Experience Expectation, perceived risk found $0.931,0.729$ and 0.818 respectively.

\section{CONCLUSION AND MANAGERIAL IMPLICATIONS}

The e-wallet is becoming popular in present era. The present study was conducted to study factors affecting e-wallet usage. The exploratory factor analysis approach was carried out to explore factors affecting ewallet usage and factor analysis yielded three factors namely perceived benefits and convenience, Experience Expectation and perceived risk. Out of the surveyed respondents 81.2 percent were using the ewallet. The e-wallet market players should keep in mind these factors while designing the marketing strategies. The market players should focus on benefits and convenience by e-wallets with ease of use, the players may design positioning on these grounds. The perceived risk is the important factor, the market players try to take steps which overcome the effect of risk. The education plays an important role in adoption of ewallets so, the market players can take benefit of that in segmentation, targeting and positioning of services it may helpful in designing the promotional programme.

\section{FUTURE REASEARCH}

The E-wallets are penetrating in Indian market rapidly. The future research can be 
ISSN 2349-2317 (Online); DOI: 10.16962/EAPJMRM/issn. 2349-2317/2018; Volume 9 Issue 4 (2018)

carried out the consumer behaviour toward the e-wallet. The research may carried out for the improvement of the e-wallet services and various factors affecting the e-wallet usage satisfaction.

\section{REFERENCES}

ASSOCHAM. (2016). M-Wallet: Scenario Post Demonetisation. New Delhi: ASSOCHAM.

BCG, G. (2016). Digital Payments 2020 The Making of a $\$ 500$ billion Ecosystem in India. Mumbai: The Boston Consulting Group.

Comviva, M. (2016). The Evolution of Digital and Mobile Wallets. New Delhi: Mahindra Comviva.

Deepak Mathur, P. P. (2015). A Survey of Epayment system in E-Business of India. International Journal of Mechanical Engineering and Information Technology, Vol.03 Issue 08 pp.1509-1518.

D. H. Shin (2009), Towards and understanding of the consumer acceptance of mobile wallet, Computers in HumanBehavior, vol. 25, no. 6, pp. 13431354

Devis, F. D. (1989). Perceived Usefulness, Perceived Ease Of Use, And User
Acceptance of Information Technology. MIS Quarterly, 13 (3), pp. 319-340.

Ho, S. M. S., and Ng, T. F. V., Customers' Risk Perceptions of Electronic Payment Systems,

International Journal of Bank Marketing, Vol.12, No.8, 1994, pp. 26-39

Hodiwalla F, Aneja D. (2016, November 21) Emergence of e-wallets in India; here is how the payments industry is growing rapidly, The Financial Express retrieved from https://www.financialexpress.com/

IMAP. (2016). Payments Industry in India / 2016. IMAP India.

Jean-Michel Sahut (2008) The Adoption and Diffusion of Electronic Wallets: The Case of Moneo, Journal of Internet Banking and Commerce.

Jocil, G. a. (2017). A Study on "Electronic Paymentsystem" - "E-Wallet". International Journal of Emerging Technology in Computer Science \& Electronics, Volume 24 Issue 3 pp.60-62.

L. D. Chen (2008), A model of consumer acceptance of mobile payment, International Journal of Mobile Communications, vol. 6, no. 1 , pp. $32-52$ 
Leon Schiffman, L. K. (2010). Consumer Behaviour (10th Edition). New Delhi: Pearson India.

Majid Taghiloo, M. A. (2010). Mobile Based Secure Digital Wallet for Peer to Peer Payment System. International Journal of UbiComp, Vol.1, No.4, pp.1-11.

Mohsen Tavakol, R. D. (2011). Making sense of Cronbach's alpha. International Journal of Medical Education., 2 pp. 53-55.

March, JG.(1978), Bounded rationality, ambiguity, and the engineering of choice, Bell Journal of Economics, Vol.9, pp. 587608.

Malhotra, N. K. (2007). Marketing research: An applied orientation. Upper Saddle River, NJ: Pearson/Prentice Hall.

Rahmath Safeena, H. D. (2012). Technology Adoption and Indian Consumers: Study on Mobile Banking. International Journal of Computer Theory and Engineering,, Vol. 4, No. 6 pp.1020-1024.

Robbins, S. P. (2009). Organizational Behavior. India : Pearson Education India.
Saini, R. (2017). Acceptability of M-wallet System in India. Asian Journal of Research in Marketing, Vol. 6, No. 4 pp. 24-29.

Sanjeev Padashetty, K. K. (2013). An Empirical Study on Consumer Adoption of Mobile Payments In Bangalore City - A Case Study. ResearchersWorld -Journal of Arts, Science \& Commerce, Vol.-IV, Issue1(1),pp.83-94.

Subbulakshmi, S. (2017) A Study on Self Concept of Students Studying in Colleges in Kanchipuram District- An Empirical Study, SYNDICATE - The Journal of Management Vol.7 pp.1-7

Teena Wadhera, R. D. (2017). Adoption of M- Wallet: A way Ahead. International Journal of Engineering and Management Research, Vol-7, Issue-4, pp .1-7.

\section{WEBSITTES}

http://www.financialexpress.com/industry/te chnology/emergence-of-e-wallets-in-indiahere-is-how-the-payments-industry-isgrowing-rapidly $/ 451008 /$ retrieved on 30.10 .2017

http://www.icommercecentral.com/openaccess/the-adoption-and-diffusion-ofelectronic-walletsthe-case-of- 
ISSN 2349-2317 (Online); DOI: 10.16962/EAPJMRM/issn. 2349-2317/2018; Volume 9 Issue 4 (2018)

mono.php?aid=38412 retrieved on http://www.indiaretailing.com/2017/02/03/re 30.10 .2017

tail/e-wallets-future-transactions-indianconsumer/ retrieved on 30.10.2017

\section{TABLES AND FIGURES}

TABLE: 1 Demographic profile of respondents

\begin{tabular}{|c|c|c|}
\hline \multicolumn{3}{|c|}{ Gender } \\
\hline & Frequency & Percent \\
\hline Male & 78 & 78.8 \\
\hline Female & 21 & 21.2 \\
\hline Total & 99 & 100.0 \\
\hline \multicolumn{3}{|c|}{ Average Age of Respondents (In Years) } \\
\hline Average Age & \multicolumn{2}{|c|}{26 Years } \\
\hline \multicolumn{3}{|c|}{ Education } \\
\hline & Frequency & Percent \\
\hline $\mathrm{HSC}$ & 1 & 1.0 \\
\hline UG (Under Graduate) & 26 & 26.3 \\
\hline PG (Post Graduate) & 65 & 65.6 \\
\hline Others & 7 & 7.1 \\
\hline Total & 99 & 100.0 \\
\hline \multicolumn{3}{|c|}{ Occupation } \\
\hline & Frequency & Percent \\
\hline Students & 64 & 64.6 \\
\hline Service & 30 & 30.3 \\
\hline Business & 2 & 2.0 \\
\hline Others & 3 & 3.0 \\
\hline Total & 99 & 100.0 \\
\hline \multicolumn{3}{|c|}{ Monthly Expenditure on Mobile } \\
\hline
\end{tabular}


ISSN 2349-2317 (Online); DOI: 10.16962/EAPJMRM/issn. 2349-2317/2018; Volume 9 Issue 4 (2018)

\begin{tabular}{|l|r|r|}
\hline & \multicolumn{1}{|c|}{ Frequency } & \multicolumn{1}{c|}{ Percent } \\
\hline Less Than Rs.250 & 39 & 39.4 \\
\hline Rs.250-Rs.500 & 33 & 33.3 \\
\hline More than Rs. 500 & 27 & 27.3 \\
\hline Total & 99 & 100.0 \\
\hline \multicolumn{2}{|c|}{ Average time spend on mobile by respondents } \\
\hline Average Usage & \multicolumn{2}{|c|}{3.42 Hours } \\
\hline \multicolumn{3}{|c|}{ Use of E-wallet } \\
\hline \multicolumn{2}{|c|}{ Frequency } & Percent \\
\hline Yes & 81 & 81.8 \\
\hline No & 18 & 18.2 \\
\hline Total & 99 & 100.0 \\
\hline
\end{tabular}

TABLE 2: Chi square test for Adoption of e-wallet and education level

\begin{tabular}{|l|r|r|r|}
\hline \multicolumn{5}{|c|}{ Chi-Square Tests } \\
\hline & \multicolumn{1}{|c|}{ Value } & df & Asymp. Sig. (2-sided) \\
\hline Pearson Chi-Square & 9.292 & & $.026^{*}$ \\
\hline
\end{tabular}

TABLE 3: Chi square test for Adoption of e-wallet and occupation

\begin{tabular}{|l|r|r|r|}
\hline \multicolumn{5}{|c|}{ Chi-Square Tests } \\
\hline & Value & df & Asymp. Sig. (2-sided) \\
\hline Pearson Chi-Square & 1.689 & & 3 \\
\hline
\end{tabular}

$5 \%$ significant level

TABLE 4: Chi square test for frequency of using E-wallet is independent of occupation

\begin{tabular}{|l|c|c|c|}
\hline \multicolumn{5}{|c|}{ Chi-Square Tests } \\
\hline & Value & df & Asymp. Sig. (2-sided) \\
\hline Pearson Chi-Square & 25.596 & 15 & $.042^{*}$ \\
\hline
\end{tabular}

$5 \%$ significant level

TABLE: 5 Reliability test (Cronbach alpha) 
ISSN 2349-2317 (Online); DOI: 10.16962/EAPJMRM/issn. 2349-2317/2018; Volume 9 Issue 4 (2018)

\begin{tabular}{|r|r|}
\hline \multicolumn{2}{|c|}{ Reliability Statistics } \\
\hline Cronbach's Alpha & N of Items \\
\hline .912 & \\
\hline
\end{tabular}

TABLE 6: KMO and Bartlett's Test

\begin{tabular}{|l|l|r|}
\hline \multicolumn{2}{|c|}{ KMO and Bartlett's Test } \\
\hline Kaiser-Meyer-Olkin Measure of Sampling Adequacy. & .888 \\
\hline \multirow{3}{*}{ Bartlett's Test of Sphericity } & Approx. Chi-Square & 1038.055 \\
\cline { 2 - 3 } & Df & 153 \\
\cline { 2 - 3 } & Sig. & .000 \\
\hline
\end{tabular}

TABLE: 7 Total Variance Explained

\begin{tabular}{|c|c|c|c|c|c|c|c|c|c|}
\hline \multicolumn{10}{|c|}{ Total Variance Explained } \\
\hline \multirow[t]{2}{*}{$\begin{array}{l}\text { Compone } \\
\text { nt }\end{array}$} & \multicolumn{3}{|c|}{ Initial Eigenvalues } & \multicolumn{3}{|c|}{$\begin{array}{l}\text { Extraction Sums of } \\
\text { Squared Loadings }\end{array}$} & \multicolumn{3}{|c|}{$\begin{array}{c}\text { Rotation Sums of Squared } \\
\text { Loadings }\end{array}$} \\
\hline & $\begin{array}{c}\text { Tota } \\
1\end{array}$ & $\begin{array}{c}\% \text { of } \\
\text { Varianc } \\
\text { e }\end{array}$ & $\begin{array}{c}\text { Cumulativ } \\
\text { e } \%\end{array}$ & $\begin{array}{c}\text { Tota } \\
1\end{array}$ & $\begin{array}{c}\% \text { of } \\
\text { Varianc } \\
\mathrm{e}\end{array}$ & $\begin{array}{c}\text { Cumulativ } \\
\text { e } \%\end{array}$ & $\begin{array}{c}\text { Tota } \\
1\end{array}$ & $\begin{array}{c}\% \text { of } \\
\text { Varianc } \\
\mathrm{e}\end{array}$ & $\begin{array}{c}\text { Cumulativ } \\
\text { e } \%\end{array}$ \\
\hline 1 & $\begin{array}{r}7.94 \\
8\end{array}$ & 44.158 & 44.158 & $\begin{array}{r}7.94 \\
8\end{array}$ & 44.158 & 44.158 & $\begin{array}{r}6.41 \\
7\end{array}$ & 35.648 & 35.648 \\
\hline 2 & $\begin{array}{r}2.34 \\
1\end{array}$ & 13.008 & 57.166 & $\begin{array}{r}2.34 \\
1\end{array}$ & 13.008 & 57.166 & $\begin{array}{r}2.53 \\
2\end{array}$ & 14.067 & 49.715 \\
\hline 3 & $\begin{array}{r}1.09 \\
9\end{array}$ & 6.106 & 63.272 & $\begin{array}{r}1.09 \\
9\end{array}$ & 6.106 & 63.272 & $\begin{array}{r}2.44 \\
0\end{array}$ & 13.557 & 63.272 \\
\hline 4 & .872 & 4.844 & 68.116 & & & & & & \\
\hline 5 & .775 & 4.304 & 72.420 & & & & & & \\
\hline 6 & .651 & 3.615 & 76.035 & & & & & & \\
\hline 7 & .620 & 3.445 & 79.479 & & & & & & \\
\hline
\end{tabular}


ISSN 2349-2317 (Online); DOI: 10.16962/EAPJMRM/issn. 2349-2317/2018; Volume 9 Issue 4 (2018)

\begin{tabular}{|l|r|r|r|l|l|l|l|l|l|}
\hline 8 & .589 & 3.274 & 82.754 & & & & & & \\
\hline 9 & .545 & 3.029 & 85.783 & & & & & & \\
\hline 10 & .505 & 2.808 & 88.591 & & & & & & \\
\hline 11 & .394 & 2.190 & 90.781 & & & & & & \\
\hline 12 & .336 & 1.868 & 92.649 & & & & & & \\
\hline 13 & .297 & 1.651 & 94.300 & & & & & & \\
\hline 14 & .268 & 1.486 & 95.786 & & & & & & \\
\hline 15 & .249 & 1.383 & 97.170 & & & & & & \\
\hline 16 & .200 & 1.108 & 98.278 & & & & & & \\
\hline 17 & .164 & .910 & 99.188 & & & & & & \\
\hline 18 & .146 & .812 & 100.000 & & & & & & \\
\hline
\end{tabular}

Extraction Method: Principal Component Analysis.

TABLE 8: Rotated Component Matrix

\begin{tabular}{|c|c|c|c|}
\hline \multicolumn{4}{|c|}{ Rotated Component Matrix ${ }^{a}$} \\
\hline & \multicolumn{3}{|c|}{ Component } \\
\hline & 1 & 2 & 3 \\
\hline I am well aware with E-wallet & .851 & & \multirow{8}{*}{$\begin{array}{c}\text { Perceived Benefits and } \\
\text { Convenience }\end{array}$} \\
\hline E-wallets are fast way of doing transaction & .806 & & \\
\hline E-wallets are user friendly & .800 & & \\
\hline E-wallet is easy to operate & .793 & & \\
\hline E-wallet provides the convenience. & .734 & & \\
\hline E-wallet saves my time & .713 & & \\
\hline $\begin{array}{l}\text { E-wallet gives flexibility for transaction at } \\
\text { any time }\end{array}$ & .708 & & \\
\hline E-wallet are easy than traditional method & .703 & & \\
\hline
\end{tabular}


ISSN 2349-2317 (Online); DOI: 10.16962/EAPJMRM/issn. 2349-2317/2018; Volume 9 Issue 4 (2018)

\begin{tabular}{|c|c|c|c|}
\hline $\begin{array}{l}\text { I don't need any training for operating e- } \\
\text { wallet }\end{array}$ & .676 & & \\
\hline E-wallet is safe & .655 & & \\
\hline $\begin{array}{l}\text { I will strongly recommend others to use E- } \\
\text { wallet }\end{array}$ & .583 & .469 & \\
\hline E-wallet saves my money & .580 & .427 & \\
\hline E-wallet use is status & & .765 & \\
\hline E-wallet usage is fun & & .710 & Experience Expectation \\
\hline E-wallet helps in controlling my transaction & & 694 & \\
\hline E-wallet has chance of fraud & \multirow{3}{*}{\multicolumn{2}{|c|}{ Perceived Risk }} & .876 \\
\hline E-wallet is risky & & & .814 \\
\hline $\begin{array}{l}\text { E-wallet allows unauthorized person to access } \\
\text { my personal information }\end{array}$ & & & .778 \\
\hline \multicolumn{4}{|c|}{ Extraction Method: Principal Component Analysis. } \\
\hline
\end{tabular}

TABLE 9: Internal Consistency

\begin{tabular}{|l|l|l|l|}
\hline S.N & Factors & No of Items & $\begin{array}{l}\text { Cronbach's } \\
\text { Alpha }\end{array}$ \\
\hline 1 & Perceived Benefits and Convenience & 12 & 0.931 \\
\hline 2 & Experience Expectation & 3 & 0.729 \\
\hline 3 & Perceived Risk & 3 & 0.811 \\
\hline
\end{tabular}




\section{List of Tables}

\begin{tabular}{|c|c|c|}
\hline Sr.N & $\begin{array}{l}\text { Table } \\
\text { Number }\end{array}$ & Description \\
\hline 1 & Table: 1 & $\begin{array}{l}\text { Demographic profile } \\
\text { of respondents }\end{array}$ \\
\hline 2 & Table: 2 & $\begin{array}{l}\text { Chi square test for } \\
\text { Adoption of e-wallet } \\
\text { and education level }\end{array}$ \\
\hline 3 & Table: 3 & $\begin{array}{l}\text { Chi square test for } \\
\text { Adoption of e-wallet } \\
\text { and occupation }\end{array}$ \\
\hline 4 & Table: 4 & $\begin{array}{l}\text { Chi square test for } \\
\text { frequency of using E- } \\
\text { wallet is independent } \\
\text { of occupation }\end{array}$ \\
\hline 5 & Table: 5 & $\begin{array}{l}\text { Reliability test } \\
\text { (Cronbach alpha) }\end{array}$ \\
\hline 6 & Table: 6 & $\begin{array}{l}\text { KMO and Bartlett's } \\
\text { Test }\end{array}$ \\
\hline 7 & Table: 7 & $\begin{array}{l}\text { Total Variance } \\
\text { Explained }\end{array}$ \\
\hline 8 & Table: 8 & $\begin{array}{ll}\text { Rotated } & \text { Component } \\
\text { Matrix } & \end{array}$ \\
\hline 9 & Table: 9 & Internal Consistency \\
\hline
\end{tabular}

